\title{
Sharing Economy in the Czech Republic
}

\author{
Marie BEDNARIKOVA and Jana KOSTALOVA*
}

University of Pardubice, Pardubice, Czech Republic; marie.bednarikova@upce.cz; jana.kostalova@upce.cz

* Corresponding author: jana.kostalova@upce.cz

\begin{abstract}
The sharing economy started to evolve significantly as a new trend at the end of last decade. An important impulse for this evolution was the technological development, which made it possible, together with the arrival of Web 2.0, to create platforms of the sharing economy. The sharing economy appears in a lot of variations, with local and worldwide accessibility, and the number of shared items is growing continuously. The focus of this paper is to map the spread of this new trend in the Czech Republic. It aims to identify individual areas of the sharing economy and to show their strengths and weaknesses. The paper includes the outcomes of a research dealing with identification of the areas of the sharing economy in the Czech Republic and with the experience with its use.
\end{abstract}

Keywords: sharing economy; peer-to-peer (P2P); categories of sharing economy; development of sharing economy in the Czech Republic

\section{JEL Classification: D16}

\section{Introduction}

Sharing Economy (SE) allows more effective optimization or resources thanks to the possibility of sharing unused property, services, or unused capital (Gurau \& Ranchhod, 2020). The main potential of this economic model lies in the possibility of its application in almost all the existing branches of economy. Sharing property is not a contemporary phenomenon. For decades, there have been services that comply with certain signs of SE. However, together with the massive development of modern technologies, with the spread of the Internet and mainly of smart phones, sharing free resources of an individual has become easily accessible and undemanding (Bardhi \& Eckhardt, 2017). The basic advantage of sharing through a technological platform is the factor of increased confidence, which is created by a mutual user evaluation system.

The society is in Stage 4 of the Industrial Revolution, which is a result of development in a lot of areas - quicker communication and work with data, new manufacturing technologies and materials, comprehensive digitalization and automation of processes (Petrjanos, 2019; Basselier et al., 2018). Within this "Revolution", networking is established among persons, machines, products, and information systems. Industry 4.0 brings new forms of economy and extends the existing forms of flexible work (Dev et al., 2019). And SE, which is connected with this trend, has become a phenomenon of the recent years (Barancova, 2017).

SE concept - Sharing is a form of a social exchange occurring between people who know each other and who do not make any profits from it. Sharing used to be a substantial part of life of our ancestors, who survived whole centuries just on the principle of sharing. It was a tool mitigating impacts of low productivity in the then world. Sharing was supported by the 
fact that people lived in relatively small communities, which enabled a higher rate of control - and thanks to the control, the community enjoyed the necessary confidence, and the confidence led to the willingness to share. (Deloitte, 2017) Even today, sharing is demonstrably a part of our lives, but to a significantly smaller extent - it is a tool for maintaining primary social bonds, especially within a family or with friends (Eckhardt, 2018). As years went by, the society moved from sharing to barter and subsequently to classic trading. Classic market models are based on a property ownership conveyance between two persons. Such a conveyance can be voluntary (by donation) or for a fee. However, SE is based on a so-called peer-to-peer (P2P) relationship, which represents direct interconnection of the supply and demand in the form of a digital platform.

At the moment, there is no generally accepted definition of the term of SE. According to the definition of Lexico, the Online Oxford Dictionary (2019), it is an "economic system in which assets or services are shared between private individuals, either free or for a fee, typically by means of the Internet." Another source describes SE as an economic model supporting utilization of possessions and enabling optimization of consumption through sharing, exchange (bartering), hiring out and lending goods and services (Botsman \& Rogers, 2010). A big advantage of SE is its ability to decrease the provider's (owner's) transaction costs and, at the same time, to contribute to a higher comfort of the service users. It is a way of the economy in which the participants prefer sharing the access to the property or services, rather than their individual possession (Matocha, 2017). Within the effort to find the best definition of the new trend, new designations are being created for SE: collaborative economy, on-demand economy, gig economy, access economy, P2P, etc.

SE Entities - In the SE environment, there are three basic entity categories - a provider, a user, and an agent. Service providers typically dispose of certain assets in the form of property, time, or skills, and they share them actively for the purpose of earnings or decreasing their costs. A service provider can be a private individual providing property or services occasionally only (a peer), or a person providing services of property within performance of their occupation (a professional provider). A user is a person that does not dispose of necessary assets, resources, or skills, and so they use services or property of a provider. Then they both use a platform created by an agent. In view of the character of the relationship a user and a provider enter into through an agent (a digital platform) as two (in most cases) non-entrepreneurs, it is necessary to consider protection of both contracting parties due to certain absence of information transparency on both sides - the contracting parties do not know each other, and in some cases, they even cannot meet personally (Elischer, 2018). In some cases, there is even no direct relationship between the user and the provider, as the provider performs a service, sends the result to the agent, who then sends it to the user and pays the provider a fee (Rehorova, 2017). In some other cases, a platform plays the role of an agent, which can be generally understood as an entity mediating communication, and it makes it possible to connect the service provider and the user. An agent usually ensures connection of owners and users through a digital platform, whether in the form of a website or, in practice most frequently, in the form of an application installed 
both by the providers and by the users in their smart phones (The Section for European Affairs of the Office of the Government of the Czech Republic, 2017).

SE Benefits - SE mitigates negative impacts on the environment, which result from consumerism of the today's society. It tries to decrease wasting (Cheng, 2016). If unused property is shared, it can prevent senseless overproduction, which can subsequently lead to a lower consumption, which is better compatible with the concept of permanently sustainable development (Marek, 2016). The SE model supposes that we can satisfy more user needs without the necessity of producing more and more (Veber et al., 2016).

Sharing property also significantly decreases the owners' transaction costs of the given property. We can divide them into searching and information costs, bargaining costs, and implementation costs. Transaction expenses are incurred in the case people have an item which they do not use or which they want to get rid of at home. However, such a sale or donation require a lot of time and energy. Nevertheless, if the seller uploads their offer to a suitable platform, the entire process becomes cheaper and less time-consuming. Thanks to suitable filters, such an offer gets quickly to those interested in it. People's willingness to share, sell, and donate increases thanks to the simplicity, and the risk that useless, but wellpreserved, items will be preserved decreases. SE came with a new model of interconnecting the supply and demand through a digital platform. For users, this means comfort, and the application is its information and communication tool. In most cases, use of applications is very simple and intuitive. For providers, this means the possibility of addressing a much larger spectrum of potential customers.

Another advantage of SE is that providers have the possibility of getting involved in the model of "microbusiness". This model is characterized by a significant rate of independence, flexibility, lower entrance barriers, and self-sufficiency (Demyanenko, 2017). SE creates more jobs, mostly with flexible working hours (Valentova, 2018). An increase in flexibility of independent workforce has a direct influence on the effectiveness and quality of the offered services (Böcker \& Meelen, 2017). SE also largely affects the existing branches of business. Traditional services, such as taxis, hotels and loans had to respond to the incoming competition in the form of SE services. Their response, in most cases, meant improvements in services for the end customer in a traditional industry. SE also makes luxury goods accessible to such users who cannot afford to own them.

SE Problems and Challenges - The biggest problem of SE is that it is not clear what belongs to the sharing economy and what is an ordinary business activity (Gonzalez-Padron, 2017; Arthurs, 2018). Some SE services are a form of lease through the Internet. Therefore, the term SE is overused (Parente et al., 2018). If a person owns something and somebody else borrows the given item through an agent (a platform) for a fee, it is not a case of sharing, but an access. It is the access economy.

However, it is obvious that the term "SE" has had great marketing potential - in the public it evokes a better feeling than the depersonalized term of "platform economy" or similar terms, and so it supports some kind of ignoring negative effects (Gregory \& Halff, 2017). This phenomenon was very well seen in the boom of SE in 2012-2013, where people practically ignored everything bad. Nowadays, people are healthily skeptical, which also 
helps to establish proper regulation of SE. For years, SE platforms belonged to the area of grey economy, and it is only now possible to regulate them somehow. Regulation is still unclear in some cases, but a few measures that keep SE within the confines of the law order have been implemented in the Czech Republic (CZ) in the last year (Pichrt, 2018).

Regulation is important not only for tax collection and lawfulness of the platform activity, but also for the answer to the question: "Who is liable for a potential damage to the property or a bodily harm?" If a society has not come across a similar situation yet, it has not probably implemented any or almost any measures or instruction how to behave in such situations and who is responsible for subsequent activities.

At the beginnings of SE, authorities did not pay much attention to this new phenomenon, particularly because they were small amounts of small platforms, often shared free of charge or just to cover the costs. As the time passed, these small businesses became, in some cases, international giants. Nevertheless, most of these platforms still simply ignored payment of taxes and tried to exist outside legally defined limits. Governments of individual countries did not catch the arrival of digital platforms, so all the measures are being taken later than desirable (Krivosova, 2018).

SE complies with the requirements concerning increasing work flexibility, but this flexibility is not counterbalanced by basic security. Platform operators are not employers and they do their best not to play this role. Therefore, there is a group of workers who are outside the protective framework of the labour law (Hulka, 2017). A typical worker is either a selfemployed person performing their activity within a so-called dependent self-employment, or a person who is unilaterally marked as a self-employed person, but they meet the characteristics of an employee (so-called bogus self-employment).

A dependent self-employed person works under the conditions that are similar to employment, but they do not enjoy the same rights and protection as employees. These persons have only limited access to social protection, or they only have minimal working condition standards (working overtime, rest periods at work, or determination of a minimum salary). Some EU countries have already implemented this term into their domestic legal orders (Spain, the Netherlands, Germany, etc.). Legislation in these countries has awarded dependent self-employed persons more social rights than standard self-employed persons better access to unemployment benefits (Portugal), mandatory participation in accident insurance (Spain) or pension scheme (Germany).

As for bogus (hidden) self-employment, they are mostly workers performing work that does not require any, or almost any, qualifications. For this reason, this work is completely replaceable and badly paid, very often below the level of the legally specified minimum salary for an employee (Darilkova, 2019). The price of an offered service is more affordable for an end user, but it is often below its real value. This is the way how e.g. freelancing platforms work. They often offer their skills below the real value of the given job. Workers get small orders, and they are forced to fulfil these orders within a very short period of time and to make sure the user actually pays them. Nobody pays these workers for the time that relates to the job but that is not a part of paid orders. 
Performance of a job through a digital platform brings the risk of dehumanization of work. Workers and users are connected remotely, without direct contact, which brings the risk of perceiving a worker as a robot, but not as a real person. Workers are available 24 hours a day, 7 day a week, and they do not have a real face. There is a risk that they will be required to work as perfectly and smoothly as machines. This problem is also connected with prices of jobs below their real values. The reason why people accept a bogus self-employment is just the unfavorable economic situation of the given employee - flexibility and the possibility of making independent decisions about the working time are disappearing in this case.

As for the social protection, the Study suggests the inclusive approach within which a group of workers in non-standard forms of employment and self-employed persons will be created (The Section for European Affairs of the Office of the Government of the Czech Republic, 2017). Therefore, this group would include all working persons, so they should enjoy the same rate of social protection.

What SE misses is the user loyalty. In the upshot, it is not important for the users with which company they will travel, but how much it will cost. Users behave similarly in all the other SE sectors (Piletic, 2018).

SE Stratification in the World - Within SE definitions, it is possible to find a number of views of SE classification. For example, there are financial and non-financial SE forms, profit and non-profit SE forms, individual and group SE forms, actual SE forms and pseudoforms of SE, communal SE forms and commercial SE forms, SE of physical assets and virtual/intangible assets, SE between two participants, SE in the form of multisided sharing (Belk, 2014; Netter et al., 2019).

For the needs of stratification, an SE classification proposal from different points of view was drawn up on the basis of the literature review and discussion of different points of view.

Most frequently, SE is structured by area of operation. From this point of view, Deloitte (2017) divides SE into areas as follows: transport, accommodation, finance, commercial premises, services and work for hire, education, working equipment and another durable property, media and cloud services. The European Commission monitors SE in the following areas: accommodation, transport, food services, household services (repairs, gardening, babysitting, etc.), expert services (IT services, accounting, etc.), finance, and other areas.

Within this classification, the Office of the Government of the Czech Republic (2017) takes account of the property that is the subject matter of SE. They divide the property into tangible (transport and accommodation) and intangible (finance, services, and education).

Veber et al. (2016) specify classification of SE segments in more detail. Their concept has the following SE segments: travelling, equipment, electronics, pets, food, learning, home, luxury goods, entertainment, leisure time, premises, work, money, fashion, transport, children, services, and agriculture. Although this classification structures another segment in detail, it does not cover sharing in virtual space at all, e.g. in the form of cloud services.

For the need of SE stratification, a two-layer structure is used. The first layer is made of SE of tangible property, which includes: transport, accommodation, commercial premises, working equipment, and another durable property (books, clothes, furniture, household goods, tools, etc.). The second layer includes SE of intangible property, such as: finance, 
services and work for hire, media (music, films, series, videos), education, and cloud services (here the cloud service provider shares hardware and software with the cloud service users for a fee)).

SE affects a number of industries, and their services are used by more and more people. Compared to traditional services and financial models, SE offers a lot of benefits. On the other hand, it is also accompanied by a lot of problems and criticism (Frenken \& Schor, 2017).

The research aims to identify the areas where SE find its use, to specify representatives of platforms existing in respective areas, and to assess the pros and cons of application of SE in these areas.

\section{Methodology}

The primary research was based on the literature review involving professional publications dealing with SE on the basis of this research. The structure of the literature search was based on the basic available analyzes in the field of SE (Deloite, 2017; Office of the Government of the Czech Republic, 2017; Veber et al., 2016; Botsman \& Rogers, 2010) and on the data from COST Action No. CA16121 - "From Sharing to Caring: Examining SocioTechnical Aspects of the Collaborative Economy". It is based on the definitions of basic terms (concept, entities, advantages and disadvantages of SE). Basic key terms were used as search criteria, mainly: SE, collaborative economy, on-demand economy, gig economy, access economy, P2P, definition of SE, pros and cons of SE etc. An important point for structuring the research was SE stratification, for which the methods of classification available in the professional publications were found and based on that we identified the main areas affected by SE in the world. On the basis of this knowledge, we made assessment of the situation in the $\mathrm{CZ}$, we found and described examples of platforms representing real use of SE in the main SE areas in CZ and in the world. Then, on the basis of the assessment of these platforms, we summarized the basic parameters typical for the respective main SE areas and identified the main advantages and disadvantages of SE in these main areas.

\section{Results}

On the basis of the literature review, we determined the basic SE areas, which were subsequently dealt with. Table 1 summarizes the areas of sharing. We chose a representative

Table 1. SE areas and their representatives in the World and in CZ

\begin{tabular}{|c|c|c|}
\hline SE areas & Representative in the world & Representative in CZ \\
\hline Transport & Uber & Uber, Lime, Rekola \\
\hline Accommodation & Airbnb, PivotDesk & Airbnb, Moje chaty, InnoCrystal, WorkLounge \\
\hline Financial area & Kickstarter & Hithit, Darujme.cz, Fundlift, Zonky \\
\hline Cloud services & Dropbox & Dropbox, Algo Cloud \\
\hline Sharing things & Library of Things & Pưjčím.to, Nevyhazujto.cz \\
\hline Work & TaskRabbit & Hlidacky.cz \\
\hline Education & Linked In Learning, Coursera, EdX & Seduo \\
\hline Media & Youtube, Netflix & Youtube, Netflix \\
\hline
\end{tabular}


of each area from the world and a representative operating in the CZ. In each platform, we also focused on the assessment of their benefits and problems.

The best-known example in the area of transport is Uber, which operates globally and offers an alternative to taxis. Uber Technologies Inc. is an American multinational transport and mobile company, which in the form of collaborative consumption enables ordering transport in a passenger car. The company was established in 2009, and it is based in San Francisco, California. The company deals with development, offering, and operation of the Uber mobile application, which makes it possible for the consumers to request a ride with a driver using their own car through a smart phone. Within a few years after its establishment, the company expanded to a lot of cities in the USA and elsewhere in the world. In the CZ, you have been able to use the service since 2014. Apart from personal transport, the company also focusses on meal distribution, they engage in a lot of charity events, they employ more women, minorities, and they also support equality. For the reason of support of healthier environment, they try to support the possibility of carpools. Since 2016, they have been dealing with testing autonomous cars, and since 2017 there has been a platform called UberFreight, which is used in cargo transport. At the beginnings of their operation in $\mathrm{CZ}$, the company was an unfair competitor to taxis, as their drivers were not required to have a taxi driver license. This serious imperfection has already been removed, and Uber drivers have to comply with the same conditions as taxi drivers, i.e. they also have to have a taxi driver license and they have to pass a topographical test. What is typical for $\mathrm{CZ}$ in the area of transport is sharing bicycles (e.g. Rekola Platform), or sharing scooters (Lime Platform). Scooters can be hired in Prague, bicycles in 10 large cities in CZ (Prague, Brno, Ostrava, Liberec, Olomouc, České Budějovice, Frýdek-Místek, Písek, Kladno, and Mladá Boleslav). The advantage of this way of transport is mainly acceleration of movement inside a city and in its surroundings using an environment-friendly way of transport.

In the area of accommodation, people can let out their homes or any other free premises they are not using at the moment. Accommodation is usually for a fee, but it is also possible to make an exchange and visit the guests in their homes next time. The most wide-spread platform making it possible to provide short-time accommodation thanks to sharing real estate with other people is Airbnb. Airbnb is a service interesting not only for real estate owners, as it offers higher appreciation of their real estate than if they rented it on a longterm basis, but the service is also attractive for those staying there, as they usually pay for a short-term real estate rent less than at a classic hotel. Airbnb charges a service fee in \% of the price of each mediated accommodation. Airbnb platform was established in 2008. Within a few years, the service has become the second most valuable start-up in the world (behind Uber). This service has been provided in the area of CZ since 2009. The income from accommodation (as well as from passenger transport) acquired through digital platforms of the Airbnb (Uber) type is subject to the income tax. On 1 January 2020, a new amendment to the act on local charges came into effect. It responds to the development of SE and introduces a fee for a stay, which replaces the existing fees for a spa and recreational stay, and the accommodation capacity fee. A specialized platform in $\mathrm{CZ}$ in the area of sharing accommodation is a platform called MojeChaty. This company mediates short-term rent of 
cottages and weekend houses all around the CZ. Due to its specialization and orientation on the Czech clientele, the growth of this platform is significantly limited. In addition to accommodation, it is also possible to share working premises. For example, there are coworking premises created for the reason of socializing. If independent professionals cannot afford their own office premises or if they need it e.g. only one day per a week, they can use coworking premises. This trend appeared as early as in 2005 in the USA, and now it has spread worldwide. As for $\mathrm{CZ}$, most of these premises are in Prague, but it also possible to find coworking centres in smaller towns all around the country. One of the most important platforms in this area is PivotDesk; in Prague e.g. InnoCrystal or WorkLounge.

What is breaking through more and more in the financial area is crowdfunding, or P2P lending. It is an alternative nonbanking way of funding, where a larger number of individuals contribute to a target amount with a smaller sum. This diversifies the risk in case a debtor fails to pay. We recognize donation-based, reward-based, lending-based, and equity crowdfunding. Kickstarter, operated by an American company established in 2009 is wellknown abroad. This platform focuses on creativity, i.e. financing projects in the areas of music, film, technologies, etc. This company operates as reward-based crowdfunding. A Czech equivalent to this platform is a platform called Hithit. A Czech project in the area of donation-based crowdfunding is a platform called Darujme.cz, which helps non-profit organizations to get donations. A platform called Fundlift acts as equity crowdfunding, where investors buy a share in a certain company. However, they do not buy directly a share in a company, but they buy securities that can be later transferred to a share in the company or bonds. The most important representative of crowdfunding in the area of P2P lending in $\mathrm{CZ}$ is a company called Zonky, with the investment group of PPF behind. The company was established in 2015. Both the creditor and the debtor have to become members of the online Zonky community. Based on a client's online inquiry, Zonky creates the rating and, depending on it, determines the interest rate. The client then draws up their story, the company displays their inquiry on the online marketplace, and investors have the chance to decide to whom they entrust their money. If there are enough investors to cover the entire required amount, Zonky enters into a contract with the client. People get a loan for cheaper there than at a bank, and people who lend money can increase the value of their savings more advantageously. The service is under the supervision of the Czech National Bank.

Cloud services serve for sharing data or saving hard drive space on your computer. Data are saved to the cloud, so they do not occupy space on your hard drive or on your mobile phone, and they are accessible from different devices. The basic version for storing a limited volume of data is usually free of charge. Data storage is also extended by accessibility of applications on the cloud. An example of a cloud service is Dropbox. The advantages of the cloud include automatic backup, the possibility of recovery of deleted data, and minimal cost of physical storage space. Algo Cloud is a Czech company with very good reputation offering its services since 1997. It is popular particularly for its professional and humane approach to users. The company offers a unique data backup system in three different locations in CZ. It places a large emphasis on security, it has its own data centre, and server administrators are available non-stop and immediately. 
Sharing things (equipment, tools, or electronics) is based on letting out and hiring things between users. In the last years, a project called Library of Things has been spreading around the world. In these libraries, people can hire tools, aids for artists, kitchen hardware, electronics, sport and travel equipment, toys, clothes, books, medical aids, etc. They pay a fee for this lending. This makes luxury things accessible also to common people. In CZ, the first library of things was opened at Goethe Institute in 2017. This library has branches in Prague and Brno. Another company called Půjčím.to works on the direct principle of sharing among people. This platform gives people the possibility of advertising their things, and it is possible to borrow from people and from rental shops. The area of sharing things includes not only lending, but also handover of useless things, e.g. in the form of a re-use center. In CZ, there is an application called Nevyhazuj to.cz. Things offered in the application can be acquired at re-use centres in a number of larger $\mathrm{CZ}$ cities.

In the area of work, it is possible to share housework and a craft. You pay for the work done through an application, or exceptionally in cash after a service has been provided. TaskRabbit is an American Company based in 2008 and operating in the USA and in Great Britain. It connects freelance work with the local demand, and it makes it possible for consumers to find immediate help with everyday tasks, including tidying-up, moving a house, delivery, and maintenance. A tasker has to be registered, and he/she is paid hourly or for an accomplished task, and a service charge is deducted from his/her pay. A portal called Hlídačky.cz was started in CZ in 2012. It offers not only babysitting, but also pet sitting, tidying-up, and a senior care. Sitters have to go through screening. This area also includes employee sharing, where a group of employers jointly hire one worker to cover the needs of different companies. This creates a full-time job for the worker.

In the area of education, there are also companies operating worldwide, such as LinkedIn Learning, Coursera, or edX. These platforms provide online courses for free of for a fee. The important platforms in the area of education also include the platforms of Wikipedia and Youtube (see below), which primarily share information at videos, but they are also very often used for education. In CZ, there is a well-known platform called Seduo, which offers education for individuals and companies. Some courses are for free, some for a fee.

The area of media mainly shares music, videos, and films. They are widely accessible thanks to platforms. Platforms usually serves not only for acquisition, but also for uploading your own production, which results in the expansion of the offer to huge dimensions. The only condition of accessibility is the Internet connection. The largest Internet server for sharing video files is Youtube. It started in 2005, and it has tens of language versions and with advertisements it is free of charge. Company Netflix, established in 1997, focusses on films, TV programmes, documentaries, etc. It makes it possible to watch films online for a fee. It has been available in CZ since 2016.

\section{Discussion about Pros and Cons of SE in the Main Areas}

In the area of transport, the main advantage is utilization of the capacity of transport means, better accessibility and variability of means of transport, including broader use of 
environmentally friendly means of transport. A disadvantage can be found in the danger for pedestrians relating to use of bicycles and scooters in town and their wrong parking outside the designated places. Provision of transport services can be an advantageous form of extra earnings for employees, but there have also been some cases of operating co-transport to the extent of a full-time work capacity without the employee legal protection.

In the area of accommodation, SE is presented as a tool that has changed the way of transport and decreased the prices of accommodation and contributed to expansion of tourism. An advantage for owners of a flat or a spare room is in extra earnings from a shortterm rent. A disadvantage of this form of accommodation on a massive scale is its impact on the housing market and the number of tourists in attractive locations. The number of rentals through Airbnb in Prague increased threefold between 2016 and 2018. Blocking flats for a short-term rent then limits the supply for ordinary living in the form of a long-term rent or sale and increases prices. A similar problem is being faced by other tourist centres, and they plan some regulation of this activity.

In the area of finance, the main advantage is extension of funding sources, particularly for individuals, non-profit organizations, and entities that cannot reach banking sources. An advantage for investors is usually a higher interest rate, but with a higher risk.

In the area of cloud services, there is a big disadvantage in inaccessibility of the data if the Internet is not available. This interrupts the access to the server. Transfer of your data to the cloud and operation of cloud applications are also being considered from the point of view of security. On the other hand, the advantages usually include lower costs, transfer of a number of activities to the provider (backup, security, ongoing update), and the possibility of using data spaces or the latest applications without huge investment costs.

The area of sharing things is mainly connected with advantages leading to the maximum possible utilization of things, their future use if the owner does not need them any longer. A disadvantage can be seen in the risk relating to the quality, and in the case of lending, also in the takeover of a thing in use.

The most important disadvantages in the area of sharing work were mentioned in section 1. However, the above-mentioned platforms bring advantages, rather than disadvantages. In particular, this refers to activities that are harder to cover with ordinary workers (babysitting, pet sitting, etc). The provider can enjoy benefits in the form of extra earnings and flexibility in providing services based on their capacity.

The extension of accessibility of information, videos, and training courses through online platforms in the area of education is a clear contribution to this area. Its advantages include worldwide accessibility and a vast range that is available. Its disadvantages are mainly relating to the fact that it is not easy to find your way through the wide range of offerings and to assess the quality of offered courses.

Similar advantages and disadvantages refer to the area of media. On the one hand, a huge growth of offerings, increased accessibility, the possibility of becoming creators and, on the other hand, a large variance in the topics and quality in the shared video and audio material. 


\section{Conclusions}

SE is a new economic model, which extends the existing standard possibilities of exchange in the society in a lot of alternatives and forms using technological means. SE affects a lot of areas, it offers sharing tangible and intangible property, and the scope of sharing and its forms are still extending. SE is applied at local, national, and particularly the worldwide levels, it increases competition, increases effectiveness in using available resources, and contributes to sustainable development in a number of cases.

The paper aims to present SE, its concept, areas of operation, benefits, problems, and challenges. The areas of operation, its advantages and disadvantages are demonstrated on examples of platforms existing at both global and national levels, i.e. platforms operating in the CZ. It is desirable to monitor the area of SE and its development, and its impact on the society. In a lot of areas, it significantly affects functioning of the society, both positively (e.g. through its contribution to sustainability), and negatively (e.g. by disadvantaging job providers within SE). It is desirable to continue analysing these phenomena and their impact on the society deeply.

Acknowledgments: This paper is an outcome of research project: "Economic, social and environmental aspects of collaborative economy from the point of view of the Czech Republic", COST Action No. CA16121 - "From Sharing to Caring: Examining Socio-Technical Aspects of the Collaborative Economy", funded by the University of Pardubice, led by doc. Ing. Liběna Tetřevová, Ph.D.

\section{References}

Arthurs, H. (2018). The False Promise of the Sharing Economy. In D. McKee, F. Makela, \&, T. Scassa (Eds.), Law and the "Sharing Economy" (pp. 55-72). University of Ottawa Press. https://doi.org/10.2307/j.ctv5vdczv.6

Barancova, H. (2017). Collaborative Economy - Digital Age and Its Reflections for Future Development of the Labour Law. In J. Pichrt, R. Bohac, \& J. Moravek (Eds.), Sharing Economy and Delicts (pp. 22-38). Praha: Wolters Kluwer ČR.

Bardhi, F., \& Eckhardt, G. M. (2017). Liquid consumption. Journal of Consumer Research, 44(3), 582-597. https://doi.org/10.1093/jcr/ucx050

Basselier, R., Langenus, G. \& Walravens, L. (2018). The rise of the sharing economy. Econ. Review, 57-78.

Belk, R. W. (2010). Sharing. Journal of Consumer Research, 36(5), 715-734. https://doi.org/10.1086/612649

Böcker, L., \& Meelen, T. (2017). Sharing for people, planet or profit? Analysing motivations for intended sharing economy participation. Environmetal Innovation and Societal Transition, 23, 28-39. https://doi.org/10.1016/j.eist.2016.09.004

Botsman, R., \& Rogers, R. (2010). What's mine is Yours: The Rise of Collaborative Consumption. Glasgow: Harper Collins Publishers.

Cheng, M. (2016). Sharing economy: a review and agenda for future research. International Journal of Hospitality Management, 57, 60-70. https://doi.org/10.1016/j.ijhm.2016.06.003

Darilkova, L. (2019). Social Protection of Workers in Sharing Economy in EU Legislation. In Z. Vrbova (Ed.), Does the Law Keep up with It?: Society and Science Dynamics at the Beginning of the 21 $1^{\text {st }}$ Century, (pp. 29-46). Praha: Ústav státu a práva Akademie věd ČR.

Deloitte. (2017). Sharing Economy - Wealth without Ownership. https://edu.deloitte.cz/m/Content/ DownloadPublication/sdilena-ekonomika-2017

Demyanenko, S. (2017). Sharing Economy as an Innovative Exchange Tool in the Area of Financial Services in the Context of Persisting Digital Revolution in the Area of the Czech Republic in 2016: Bachelor Thesis. Prague University of Economy.

Dev, N. K., Shankar, R., \& Qaiser, F. H. (2019). Industry 4.0 and circular economy: Operational excellence for sustainable reverse supply chain performance. Resources, Conservation and Recycling, 153, 104583. https://doi.org/10.1016/j.resconrec.2019.104583 
Elischer, D., \&; Macek, O. (2019). Sharing Economy, or Where is the Burden of Responsibility? In J. Pichrt, R. Bohac, \& J. Moravek (Eds.), Sharing Economy and Delicts (pp. 73-88). Praha: Wolters Kluwer ČR.

Frenken K., \& Schor, J. (2017). Putting the sharing economy into perspective. Environmental Innovation and Societal Transitions, 23, 3-10. https://doi.org/10.1016/j.eist.2017.01.003

Gonzalez-Padron, T. L. (2017). Ethics in the sharing economy: creating a legitimate marketing channel. Journal of Marketing Channels, 24(1-2), 84-96. https://doi.org/10.1080/1046669x.2017.1347005

Gregory, A., \& Halff, G. (2017). Understanding public relations in the 'sharing economy. Public Relations Review, 43(1), 4-13. https://doi.org/10.1016/j.pubrev.2016.10.008

Gurau, C., \& Ranchhod, A. (2020). The sharing economy as a complex dynamic system: Exploring coexisting constituencies, interests and practices. Journal of Cleaner Production, 245, 118799. https://doi.org/10.1016/j.jclepro.2019.118799

Hulka, T. (2017). New Forms of Flexible Employment, or Endangering Security? In J. Pichrt, R. Bohac, \& J. Moravek (Eds.), Sharing Economy and Delicts (pp. 39-49). Praha: Wolters Kluwer ČR.

Krivosova, M. (2018). The development of sharing economy in the Czech Republic: Quantitative media analysis. Master Thesis. Prague University of Economy.

Marek, M. (2016). Sharing Economy and Its Place in the Modern Economic System. Bachelor Thesis. Prague Charles University.

Matocha, J., \& Svoboda, J. (2017). The Undefined Term of Sharing Economy as a Tool for Bypassing Regulation. In J. Pichrt, R. Bohac, \& J. Moravek (Eds.), Sharing Economy and Delicts (pp. 215-225). Praha: Wolters Kluwer ČR.

M. Eckhardt, G., \& Bardhi, F. (2018). The Sharing Economy Isn't About Sharing at All. Harward Business Review. https://hbr.org/2015/01/the-sharing-economy-isnt-about-sharing-at-all

Netter, S., Pedersen, E. R. G., \& Lüdeke-Freund, F. (2019). Sharing economy revisited: Towards a new framework for understanding sharing models. Journal of Cleaner Production, 221, 224-233. https://doi.org/10.1016/j.jclepro.2019.02.225

Parente, R. C., Geleilate, J. M. G., \& Rong, K. (2018). The Sharing Economy globalization phenomenon: a research agenda. Journal of International Management, 24(1), 52-64. https://doi.org/10.1016/j.intman.2017.10.001

Petrjanos, V. (2019). Industry 4.0 Will Mean Flexibility without Negative Impacts on the Quality and Production Costs... CFOworld. https://cfoworld.cz/trendy/prumysl-4-0-bude-znamenat-flexibilitu-bez-negativniho-vlivu-nakvalitu-a-vyrobni-naklady-4883

Pichrt, J. (2018). Memoranda, Accommodation Costs ... and What Else? In J. Pichrt, R. Bohac, \& J. Moravek (Eds.), Sharing Economy and Delicts (pp. 11-27). Praha: Wolters Kluwer ČR.

Piletic, P. (2018). 7 Major Disadvantages of the Sharing Economy. CustomerThink. http://customerthink.com/7-majordisadvantages-of-the-sharing-economy/

Rehorova, L. (2017). Economy of Online Platforms and Transformation of the Labour Market. In J. Pichrt, R. Bohac, \& J. Moravek (Eds.), Sharing Economy and Delicts (pp. 50-62). Praha: Wolters Kluwer ČR.

The Section for European Affairs of the Office of the Government of the Czech Republic. (2017). Analysis of Sharing Economy and Digital Platforms. The Office of the Government of the Czech Republic.

https://www.vlada.cz/assets/urad-vlady/poskytovani-informaci/poskytnute-informace-nazadost/Priloha_4_Material_Analyza.pdf

TNS Political \& Social. (2018). Report The use of the collaborative economy. https://publications.europa.eu/en/publication-detail/-/publication/34eb3c1f-cb6f-11e8-9424-01aa75ed71a1

Veber, J., Krajcik, V., Hruska, L., \& Makovsky, P. (2016). Sharing Economy. Praha: VŠPP.

Valentova, M. (2018). Sharing Economy - A New Type of Business. Portal Pohoda. https://portal.pohoda.cz/propodnikatele/uz-podnikam/sdilena-ekonomika-\%E2\%80\%93-novy-druh-podnikani/

Zervas, G., Proserpio, D., \& Byers, J. W. (2017). The Rise of the Sharing Economy: Estimating the Impact of Airbnb on the Hotel Industry. Journal of Marketing Research, 54(5), 687-705.

https://doi.org/10.1509/jmr.15.0204 